\title{
Open Universities: the next phase
}

\author{
Alan Tait \\ The Open University, Milton Keynes, UK
}

\begin{abstract}
Purpose - The purpose of this paper is to report on research on the views of Presidents and Vice Chancellors of Open Universities of current threats and opportunities for their institutions as the author marks the 50th anniversary of the first Open University in the UK established in 1969. The paper offers a historical account of the development of the Open University model, and assesses the extent to which it remains in the key position as owner of innovation in the higher education sector.

Design/methodology/approach - Interviews were conducted with leaders of Open Universities or distance teaching universities. They covered a total of 14 universities.

Findings - The replies from institutional leaders reveal the current developments, opportunities and strategic challenges of the universities. It is suggested that the digital revolution along with a wider range of environmental changes for higher education have substantially eroded the first-mover advantage that Open Universities had undoubtedly enjoyed in the first 25 years.

Originality/value - The paper concludes that there are significant concerns that innovation in Open Universities is not sufficiently embedded to ensure that their contribution to the UN Sustainable Development Goals will be maximised, or even in some cases their survival, and that a key but undervalued element is leadership development for innovation and change.
\end{abstract}

Keywords Open education, Open University, Sustainable development goals,

Leadership in distance and online learning

Paper type Research paper

\section{Introduction}

This paper reports on an increasing number of recent commentaries expressing concern about the performance and achievement of Open Universities some 50 years after the establishment of the new model for a university, and assesses the sustainability of the Open University model for the next 15 years as governments seek to fulfil the UN Sustainable Development goals (SDGs). The paper also reports on a small investigation of attitudes to these issues from a roundtable of Open University Presidents, Rectors and Vice Chancellor who met in 2017 in Toronto, and identifies the need for renewed international programmes of leadership development as key to the future of their institutions.

Open Universities in the modern sense have a record of nearly 50 years of operation, dating from the foundation of the Open University UK in 1969. There are other claimants to the title of first Open University, namely, the University of London External Examinations system, from 1858, and UNISA, the University of South Africa, from 1948 onwards. However, a recognisable Open University using distance education as a single mode of delivery is about 50 years old. 1969 was the same year that Neil Armstrong first walked on the moon, and while there was more profile for that event than for a university of a new type established in the UK, nonetheless the first ten years of the Open University also generated enormous excitement. Back in 1981, Daniel and Stroud (1981) were moved to write:

A revolution in education was proclaimed with appropriate hyperbole, buses were rented with the international academic jet-set of academic pilgrims descending on Milton Keynes to watch the OU

(C) Alan Tait. Published in the Asian Association of Open Universities Journal. Published by Emerald Publishing Limited. This article is published under the Creative Commons Attribution (CC BY 4.0) licence. Anyone may reproduce, distribute, translate and create derivative works of this article (for both commercial and non-commercial purposes), subject to full attribution to the original publication and authors. The full terms of this licence may be seen at http://creativecommons.org/licences/by/4.0/legalcode

It is a pleasure to acknowledge support from Sir John Daniel and to thank the university presidents/ vice chancellors and their representatives who gave time to supply information.

vice chancellors and their representatives who gave time to supply information. 
AAOUJ

13,1

campus rising from the mud, and governments of many political hues, noting an Open University to be the educational equivalent of an airline in terms of international status, sponsored similar projects (p. 147).

In the near half-century since then some 60 Open Universities or single-mode distance teaching universities (DTUs) have been established, with the largest number being found in Asia, followed by the regions of Europe and Africa. Latin America by contrast has very few DTUs, given its huge population, and some notable countries did not take up the model at all in the first phase, including Australia, France, Russia and the USA. There is, of course, much distance and online education in these countries, and in the last decade or so new online colleges and universities have been widely established, many of them for-profit, with a concentration on work-related programmes.

From the early days, there has been critical comment from within the Open University movement itself about the strength of the model and its sustainability for the future. Already by 1982, Keegan and Rumble (1982), in an early work on Open Universities around the world, asked questions such as "Will DTUs survive?" and "Are DTUs really necessary?" (p. 243). Later, in another volume on Open Universities, Mugridge (1997) posited that "The future of university education, particularly perhaps at a distance, lies not with the large Open Universities catering to massive numbers of students, but to extended networks of smaller institutions" (p. 169).

However, in the course of the 1980s and 1990s, Open Universities in some countries grew to enormous size, counting their students in the millions, notably India's Indira Gandhi National Open University (IGNOU), China's China Central Radio and TV University (CCRTVU - now the Open University of China), and Turkey's Anadolu University in its distance teaching faculty.

At this point, Daniel (1996) singled out a subgroup of large Open Universities, coining the term Mega universities to signify DTUs with more than 100,000 students. He noted competitive advantage as the core explanation for the rapid growth of these Mega universities, in addition to their cost advantage and their capacity to pioneer innovations in learning technologies. He also commented that competing higher education institutions had few strategies for teaching working adults or those who could not come to campus.

Starting with Daniel's central notion of the competitive advantage of Open Universities and building on the further work of Tait (2008a), we can summarise the first-mover advantage for Open Universities in 1970-1990s as having various components:

(1) vision and mission: the courage to advocate and operationalise the move from an elite to a mass HE system, with notions of openness and access;

(2) innovation in learning and teaching: the admission of non-traditional student cohorts, usually people in employment or with family responsibilities, which demanded a new flexible student-centred practice;

(3) innovation in technologies for learning: initially, this was based on innovative developments in instructional design, combined with TV and radio, and today with online teaching, peer learning, OER's, MOOCs and other online activities;

(4) innovation in educational logistics: the development of industrial-style management of services to students in large numbers, of high quality, and with an industrial-style focus on scheduling; and

(5) significant scale: breaking the mould of craft-based teaching to create university systems of hitherto unimagined scale.

\section{Challenges for Open Universities}

However, these first-mover advantages have now been substantially eroded. Other universities, both public and private, are adopting these practices as their own, enabled by 
digital technologies along with a change in the culture of higher education for which Open Universities can fairly claim responsibility (Scott, 1995). In the recent period, at least four Open Universities in Europe have been threatened with closure or merger, either because of these competitive challenges and/or perceptions of their own poor performance. The narrative of paramount leadership by Open Universities for innovation, inclusion and social justice has begun to be challenged by a number of contemporary commentators, who in one way or another identify the spread of innovation elsewhere in the higher education sector as threatening for the place of Open Universities in that landscape. A summary of recent critical accounts is given below:

(1) Garrett (2016) reporting on the Open Universities of the Commonwealth in 2016 makes three core points. First, he identifies that about half of the distance teaching institutions that he has examined "have suffered recent enrolment decline or loss of market share, along with financial difficulty in some cases" (p. 41). In other words the forward march of as many as 50 per cent of Open Universities has been halted, which calls into question the sustainability of the institutional model in too many cases. Second, Garret points out the paucity of performance data, and that this may conceal poor student performance and in particular graduation rates. In the absence of data the challenge to quality of both supposed and real "drop out" impacts negatively on reputation and recruitment. Third, Garrett points to the challenges of distance and e-learning to provide adequate student support in particular for students who come from less advantaged backgrounds, socially and educationally, and who are the core target groups for Open Universities. Nonetheless Garrett concludes optimistically, perhaps more so than his own evidence supports, on the future role that Open Universities can play as higher education opportunity expands on a global basis. This is in significant part because competition in the form of online offerings of quality and at scale have not yet been widely delivered by other universities, a view not shared by Open University leaders as reported below.

(2) Paul (2016) alludes to a similar nexus of difficulties in his discussion of the challenges for "brand differentiation" for Open Universities today, faced with digital innovation in a wide range of other higher education institutions. He also notes the capacity for resistance to change in Open Universities, in particular as regards the realisation of the digital revolution for learning and teaching.

(3) In 2017, the Commonwealth of Learning published a report of headline data on the 27 Open Universities of the Commonwealth, and while avoiding any critical analysis permits itself to comment on a perceived gap in relating "missions of the universities to outcomes, and the undertaking of performance evaluation to record real achievements in terms of learner progress and success" (Commonwealth of Learning, 2017, p. 20). The gap between mission and delivery in the practice of 12 Open Universities had already been observed in detail, raising concern about the extent to which rhetoric had outrun achievements (Tait, 2013).

(4) Weller (2017) acknowledges the current challenges for the Open University UK, in particular as they derived from a high tuition fee policy in England from 2010, and then generalises his remarks more widely to argue that notwithstanding these challenges the strengths of a University dedicated to part-time and online learning outweigh the threats of universities for whom this will never be more than a marginal preoccupation. Organising his thoughts at a number of levels he makes two important further points. First, that Open Universities need to redefine "what constitutes an Open University", and in particular introduce and support Open 
AAOUJ

13,1

Educational Practice; and second, in more detail use Open Educational Resources in its own learning and teaching strategy, rather than propose their use at a more general level.

This overview aims to provide a framework for discussion of this set of strategic challenges and opportunities for the next phases of development of Open Universities.

\section{The views of Open University leaders}

In order to provide a basis for discussion at the 2017 Toronto Roundtable of Open University Presidents, Rectors and Vice Chancellors, invitations were sent to all leaders of Open Universities or DTUs in the International Council for Open and Distance Education (ICDE) membership, asking them to provide information through interviews (see Appendices 1 and 2 for the questions and a list of participants). In the event 14 universities responded, and their replies are summarised below. While the limited size of the sample cannot make this summary representative, it does provide an insight into understanding by institutional leaders of current developments, opportunities and strategic challenges, and stimulates a number of questions. Information was collected under the following headings.

\section{Context}

Student number trends. There is no clear pattern but wide variety reflecting a range of national contexts. Where there is a continuing rise in numbers studying in Open Universities it is primarily, though not entirely, found in countries with expanding secondary school provision and buoyant repressed demand for higher education, such as India, Nigeria and South Africa. But there are also increases in Germany, Italy and Quebec. In recruiting students, Open Universities face challenges of demographics, notably a decline in the number of people seeking lifelong education at undergraduate degree level together with more intense competition. In Indonesia, the achievement of graduate status by most of the nation's school teachers, who have made up a significant majority of Universitas Terbuka's students, has caused a decline in student numbers and led the University to expand its range of programmes. The Open University UK has been hit hard by a change in government funding in England that has caused fees to rise very significantly and student numbers to decline sharply, by as much as one-third, over the last seven years. In another case an Open University was not highly regarded in its country, which constrained recruitment.

Age. There is wide variation but a dominant trend that the student age profile is getting younger, although not extending to school leavers in most cases. Exceptions include South Korea where the 25-39-year old cohort is in decline and numbers of older students are on the increase, and Italy where the over 50-year-old cohort is the largest.

Gender. It is widely though not universally true in this sample that proportions of female students equal or exceed those of men (e.g. up to 70 per cent women in the Korean National OU).

Previous education. There is broad variation in trends here, but with a widespread increase in the number of students of lower previous educational background enrolling at bachelor level. However, some Open Universities have a significant appeal to students who are already well qualified but wish to continue learning later in life.

University income. The proportion of Open Universities' income coming from government grants varies widely. The most dramatic change has been the radical shift in policy in higher education in England, which has seen most government grant eliminated, to be replaced by tuition fees. This is the primary, although not the sole cause, of the marked decline in student numbers at the Open University UK referred to above.

Proportion of national higher education enrolment in Open Universities. Here again there are significant variations because Open Universities range so greatly in size. 
Challenges. Many Open Universities are experiencing severe competitive threat from other local universities or from foreign entrants who are taking advantage of new technologies to move quickly, sometimes more quickly than Open Universities can, into the online space, and to recruit adults already in employment to compensate for demographic downturns in school leavers. More than one Open University notes the damage done to the reputation of online learning by poor quality and inadequately regulated competition. One Open University has developed a campus-based operation which now enrols as many students as its distance cohort.

Competition. A minority of Open Universities retain their assured position either because of lack of interest from other universities or because government protects their privileged position in offering distance and online learning. However, the majority report a severe level of competition that erodes the early status of Open Universities as the sole providers of opportunities for part-time home-based study and the main promoters of innovation at scale.

\section{Innovation and technology}

All respondents were committed to a vision for online study and digitally supported student administration, but they have travelled very different distances on that journey so far. Progress, however, is not necessarily a function of developing or developed country status. Some Open Universities make an explicit commitment to the development of mobile learning. Some have made progress with learning analytics while some aspire to do so. Privacy laws inhibit progress with learning analytics in a minority of countries. A minority of Open Universities have produced MOOCs. Only one Open University reported a major commitment to OERs for its own practice, and has evidence that OER use in course production reduces time and cost. A minority declared themselves to be already fully online providers or close to that goal. Several mentioned closing regional centres. The pedagogy of online learning was explicitly mentioned by only two respondents as being central to the research identity of the university. A networked system of international partnerships has been established by UNINETTUNO of Italy and represents a major element of its innovation. Rethinking curriculum for competency-based learning for adult learners in the workplace was a priority for one Open University. Resistance to change by academic staff and the need for professional development was an explicit concern of a minority, as was the need for improvement of digital skills in students.

\section{National ICT infrastructure, assessment, access, student support}

A range of Open Universities lobby governments in order to increase the number of Wi-Fi hotspots; create a national platform for e-learning; meet the needs of rural populations and prisoners; and reduce cost of broadband. One Open University had received earmarked government funding for its own ICT infrastructure.

In the area of assessment there are widespread developments, including the move to online examinations; an overall reduction of assessment; online marking and the digitalisation of scripts; more automated assessment and feedback. A minority acknowledge that change is slow, sometimes because of concerns expressed by academic staff.

Access, openness and flexibility remain a concern to the majority of Open Universities. Current reforms include restraint on increasing course fees; more flexible start times for 
AAOUJ

13,1

courses; the development of a wider range of local centres; assessment of prior learning; programmes for refugees; and links to employers.

Student support is also under review in a majority of Open Universities in the sample. Notable is the use of more advisors and e-tutors with more flexible availability, supported in some instances by data driven from learning analytics. Personalised learning was emphasised as an avenue for the future by one Open University, and continued attention to the needs of minorities by others. Careers guidance was also noted as a rising priority by one Open University. Rather surprisingly, only one Open University explicitly mentioned the challenge of student drop-out.

\section{Completing the move to mass higher education}

The UN SDGs provide a framework for future priorities. Unlike the earlier Millennium Development Goals, the SDGs explicitly embrace tertiary education, including university and lifelong learning, and the supply of teachers. They commit governments by 2030 "to ensure equal access for women and men to affordable and quality technical, vocational and tertiary education, including university" (UNESCO, 2016).

Such a significant ambition means, in effect, extending the move to mass higher education to middle income and poorer countries. The growth in numbers will be primarily in the continents of Asia, Africa and Latin America, rather than Europe and North America where participation rates in higher education already reach up to 85 per cent. Europe and North America, however, continue to have marked patterns of exclusion and disadvantage as well as wider challenges of economic and social development, and therefore also need further reform and innovation in higher education. Clearly, the challenge to Open Universities in Europe and North America for the next phase of development will be different from that in Asia, Latin America and Africa, where prima facie the need for new and large scale innovative institutions such as Open Universities remains central.

In addition to growth in the number of places in the tertiary sector, the UN SDGs also propose quality as a priority, as well as equipping students with knowledge and understanding of the concept and practice of sustainability. Quality represents a multi-faceted and contested range of issues, with both objective and subjective dimensions. The reputation of some Open Universities is acknowledged in some places to be weak, for both objective and subjective reasons. Quality in universities that define excellence by exclusion - the large numbers of applicants for a limited number of places - dominate in in professional and public "commonsense" definitions of what quality is. However, for Open Universities and other higher education institutions that seek to include participants from non-traditional groups whether defined by socio-economic class, ethnicity, rurally, gender or some combination of these, a definition of quality lies in the balance of risk taken in admission with outcomes of student success. However by definition when these factors are combined with part-time rather than full-time study, with students in the workplace and often having family responsibilities, student failure is not going to be limited to 1 or 2 per cent as it can be in élite universities. Open Universities could make a major contribution to both quality concepts and quality outcomes in mass higher education by addressing the issue in the context of the SDGs for 2030. This demands advocacy in public and governmental spheres in order to claim and demonstrate a significant share of the public discourse in how quality is conceived and rewarded.

Equally, with such a large proportion of Open University students already in the workplace, Open Universities are in a strong position to offer leadership in re-engineering curricula across all subject areas to develop a workforce and a citizenry knowledgeable about the principles and practice of sustainability. Innovation in curriculum is not in general the strongest element of innovation in an Open University profile, which has centred on mission and technologies for learning and teaching. The Open University UK, however, in 
its first 25 years attempted to acknowledge the inter-disciplinary nature of knowledge, in recognition of the "real world" experience of its adult learners, and went so far as to introduce a range of topic-based multi-disciplinary courses which did not start from disciplinary bases at all, known as University or "U" courses, such as "Risk" and "Enquiry". Increased competition, however, during the period 2000-2010 saw retreat to more conventional degree profiles such as those found at other universities, and the advent of cost centre budgeting has made collaborative work across faculty boundaries less attractive for faculty leaders. However, with the issue of sustainability placed at the heart of humanity's concern by the UN and most governments world-wide, it is possible to argue that no qualification should fail to educate its graduates on the theme. This goes much further than the introduction of a limited number of modules or qualifications in the field of environmental science, to a vision that includes sustainability in all qualifications, whether in science and technology, social science, business and management, or indeed the humanities.

While the challenges for poor, middle-income and richer countries are clearly different, contributing to social and economic development at scale through educational interventions of an innovative nature is a task with significant common elements for which co-operation and collaboration amongst Open Universities at the global level would be invaluable. Tait (2013) proposed a framework of development concepts for Open University activity using Sen's capability approach, which is relevant for this discussion. In particular it is asserted that market analysis driven recruitment while necessary is on its own inadequate for Open University missions that are driven by concepts of development or social justice, as so many of their mission statements declare. Market response has to be accompanied by identification of those who do not participate in higher education for historic reasons associated with socio-economic status, gender, rurality and disability, and recruitment, fee levels, and student support strategies need to be tailored accordingly.

\section{Innovation for survival}

As well as the potential to grow the domestic capacity of higher education through Open Universities, the expanded number of places will also be provided in part by student mobility to other countries; increased participation from foreign universities developing local campus and online operations; and renewed competition from local universities offering blended and more flexible patterns of study. Are Open Universities in the strongest position to contribute substantially to the SDG goals, in terms of both scale and quality? And has their achievement of the last 50 years led governments around the world to see them as continuing to be vital drivers of innovation in higher education at scale?

This takes us to the concluding section of discussion: the centrality of innovation to the identity and resilience of the Open University model. A recent report in Innovation in Online Learning has 27 case studies of which four only are from Open Universities, suggesting that innovation in this field is seen as lying primarily outside that sub sector (Contact North, 2017a). A further report on innovation specifically in the "World's Open Universities" lists 27 such innovation on topics such as learning design, mobile learning vans, student support, learner authentication for assessment, on demand examinations and library services (Contact North, 2017b). While this list is not exhaustive it is suggested here that these innovations, valuable though they may be in a specific country, are no more than marginal to the core character of Open Universities, and in some cases do not represent innovation on an international scale at all. One innovation only deals with Open Education which as a cluster of streams of activities does represent major opportunities to revisit and revise the Open University model.

So do Open Universities risk becoming the equivalent of the mainframe computer companies that did not notice or prepare for the arrival of personal computers, and who disappeared? Marginal innovation as reported on above is not, it is argued here, going to 
AAOUJ

13,1

provide Open Universities with what they need to validate their identity for the next period of say 15 or so years, and in particular to fulfil the SDG's. Rather what is needed is a substantive new proposition that once again combines vision and mission with new technology assemblages and combinations, which was essentially the brilliance of the early Open University model. Other universities then did not have a contemporary vision of who could and should study in a university, and indeed many actively opposed such a vision, and neither did they see in the recombination of existing broadcast and multimedia with pedagogies the possibilities for rethinking learning and teaching. We have seen enough of the potential for the restructuring of industries through the digital revolution to know that there is no guaranteed place for Open Universities in the landscape of higher education: it will have to be earned once again.

It is not possible for this paper to specify what the new innovative breakthroughs could or should be for Open Universities in all their variety in so many different countries and societies. It is possible, however, to suggest the most likely areas in which innovation breakthroughs may once again be created. They all exist already, as did cameras and mobile phones separately when they were first combined by Samsung in 2000 (Digital Trends, 2013):

(1) The rethinking of the concept of Open Education, of which there are many current constituent parts in rapid development, including Open Educational Resources and Open Education Practice, MOOCs, badging as opposed to formal qualifications, and their continuing incorporation into Open University practice (see Weller, 2017).

(2) Informal learning, to align and complement the extraordinary amount of informal learning taking place through interrogation of digital resources by adults and children outside educational institutions. This may also lead to curriculum innovation which is more co-operatively developed and learner led.

(3) A further rethink of what sort of qualification new cohorts of learners want and need. The continuing near total dominance of the bachelors, masters and $\mathrm{PhD}$ structures risk being too inflexible and lengthy for many part-time adult learners.

Some combination of these and no doubt other ideas may be the elements for recombining into a revolutionary and compelling offer such as was pioneered by Open Universities from 1970 s to 1990s. However, it is not possible or appropriate to prescribe what the core elements of innovation are, but more fruitful to argue that reimagining the Open University model is necessary, and to conclude with some comments on how the environment for such innovation can be created.

I owe to a former colleague at the Open University UK, Professor David Vincent, the term "founding father syndrome": the set of attitudes held by colleagues who are trapped emotionally and intellectually in the early institutional model and are unable or unwilling to consider the need for its revision, and to imagine new avenues for development personal communication. Resisting this syndrome has been observed to be challenging in a number of Open Universities around the world.

The familiar ways in which institutions have resisted the domination of such reactionary and conservative attitudes have included:

(1) appointment of outsiders in leadership positions for the senior team, as well as the professional and academic cohorts;

(2) exposure of Open University staff to a range of external environments; and

(3) strategic management activities such as scenario planning, which are intended to support the imagination of a range of futures.

All of these have something to contribute, though none guarantee success. The particularly hard balance to achieve is to maintain deep knowledge of the field of Open Universities and 
open and online education with the integration of innovations from elsewhere. Open Universities have a tendency because they are unusual and indeed often unique in their own countries to become a world in themselves and to overlook what is happening outside their own environments. The speed of innovation in digitally supported learning and teaching in a range of other institutions makes that a singularly serious vulnerability today.

\section{Leadership development}

Finally, these issues create a pressing agenda for leadership development in Open Universities. In some countries leadership is provided through political appointment rather than ability, and the record is in a number of places poor. In other countries Open Universities are not seen as high status or prestige institutions and do not attract the best candidates. In some societies institutional leaders are always appointed from within, and by election. In others leaders are almost always appointed externally and by open selection of the external field. There have been effective and ineffective institutional leaders using any of these processes for it to be impossible to say that one approach trumps all. However, the need to deliver radical indeed revolutionary change for Open Universities today demands institutional leaders of the highest calibre.

Over and above appointment of leaders of the best quality the need for leadership development at all levels in the organisation is pressing, across academic and professional cohorts. Paul (1990) identified amongst a range of factors for successful leadership in this field the need to be open to learning and to seek to create a learning organisation, and this is no less true now than at the time of writing. A transformational style of leadership is identified by Tait (2008b), who argues that the following capacities are essential:

- an openness to the contested values of both society and the contribution that post-secondary and higher education makes to it domestically and globally;

- the imagination of educational opportunity as being other than it is now, in the face of established political, social and professional interests;

- the invention and management of learning and teaching systems that are radically different in the ways in which they use academic labour to provide programmes of study at scale and quality; and

- the competence to integrate complex systems developed with a division of labour that can be industrial in nature (p. 505).

A more recent source also identifies a crucial competence for institutional leaders in this field to be that of "the ability to create conditions for innovation via a transformative leadership style" (Beaudoin, 2015, p. 41). There is therefore longstanding commentary to the effect that leadership development for this field has been less attended to than optimally it could have been, and to suggest outlines as to what it should be. At the same time a number of key professional associations all have a record of contribution to leadership development in this field, including the ICDE, the Asian Association of Open Universities and the European Association of Distance Teaching Universities. To conclude, however, in order to ensure the continued contribution that Open Universities present and future can surely make to the SDGs to which our governments have committed it is necessary to reemphasise and restate the importance of leadership development, relevant priorities arising from this research might include.

Leadership for:

- challenging policy environments;

- quality and reputation;

- institutional change and the digital revolution; and

- sustainability across the institution. 
AAOUJ

13,1

22

\section{References}

Beaudoin, M. (2015), "Distance education leadership in the context of digital change", Quarterly Review of Distance Education, Vol. 16 No. 2, pp. 33-44.

Commonwealth of Learning (2017), "Open universities in the commonwealth: at a glance", Commonwealth of Learning, Burnaby, available at: http://oasis.col.org/handle/11599/2786 (accessed 20 November 2017).

Contact North (2017a), "International pockets of innovation", available at: https://teachonline.ca/ pockets-innovation/international (accessed 20 November 2017).

Contact North (2017b), "26 breakthrough innovations at the world's open universities", available at: https:/teachonline.ca/sites/default/files/pdfs/26_breakthrough_innovations_at_the_worlds_ open_universities.pdf (accessed 20 November 2017).

Daniel, J. and Stroud, M.A. (1981), "Distance education: a reassessment for the 1980s", Distance Education, Vol. 2 No. 2, pp. 146-163.

Daniel, J.S. (1996), Mega-Universities and Knowledge Media, Technology Strategies for Higher Education, Kogan Page, London.

Digital Trends (2013), "From J-Phone to Lumia 1020: a complete history of the camera phone", available at: www.digitaltrends.com/mobile/camera-phone-history/ (accessed 20 November 2017).

Garrett, R. (2016), "The state of open universities in the commonwealth: a perspective on performance, competition and innovation", available at: http://oasis.col.org/handle/11599/2048 (accessed 20 November 2017).

Keegan, D. and Rumble, G. (1982), “The DTU's: an appraisal”, in Rumble, G. and Harry, K. (Eds), The Distance Teaching Universities, Croom Helm, London, pp. 225-248.

Mugridge, I. (1997), “Conclusion”, in Mugridge, I. (Ed.), Founding the Open Universities, Essays in Memory of G Ram Reddy, Sterling Publishers, New Delhi, pp. 166-171.

Paul, R. (1990), "Open learning and open management, leadership and integrity in distance education", Kogan Page/Nicol Publishing, London and New York, NY.

Paul, R. (2016), "Open universities: a storied past but an uncertain future?", Distance Education in China, Vol. 11, pp. 5-16.

Scott, P. (1995), The Meanings of Mass Higher Education, SRHE/Open University Press, Buckingham.

Tait, A. (2008a), “What are open universities for?”, Open Learning, Vol. 23 No. 2, pp. 85-93.

Tait, A. (2008b), "Leadership development for distance and e-learning”, in Evans, T., Haughey, M. and Murphy, D. (Eds), International Handbook of Distance Education, Emerald Group Publishing, Bingley, pp. 499-511.

Tait, A. (2013), "Distance and e-learning, social justice and development: the relevance of capability approaches to the mission of open universities", The International Review of Research in Open and Distributed Learning, No. 14, p. 4, available at: www.irrodl.org/index.php/irrodl/article/view/ 1526/2632 (accessed 20 November 2017).

UNESCO (2016), “Unpacking sustainable development goal 4 - education 2030", available at: http:/ unesdoc.unesco.org/images/0024/002463/246300E.pdf (accessed 20 November 2017).

Weller, M. (2017), "My part in the battle for open (universities)", The Ed Techie blog, 25 October, available at: http://blog.edtechie.net/ou/my-part-in-the-battle-for-open-universities/ (accessed 20 November 2017).

\section{Appendix 1. Questions for interviews with Open University leaders}

Context:

(1) How many students are currently enroled and how are these numbers changing?

(2) How is the profile (age, gender, previous education, etc.) of your student body evolving?

(3) How does the income of your University break down between government grants and student fees? 
(4) What proportion of the total higher education enrolments in the country are accounted for by your University?

Strategic directions:

(1) What is the most important opportunity facing your University?

(2) What is the most important challenge facing your University?

(3) How is the competitive environment of higher education in the country changing? Innovations

Specific questions:

(1) What is your University's most successful recent innovation or development?

(2) How is your University taking advantage of developments in technology?

(3) What new delivery tools and resources for learning are your university using?

- What improvements would you like to see in the country's technological infrastructure?

- Is technology changing the ways you assess students? Which new models of assessment is your university using?

(4) What specific steps are you taking to expand access, openness and flexibility at your university?

(5) How is your approach to student support evolving?

\section{Appendix 2. List of Open Universities interviewed or which replied in writing}

(1) B.R. Ambedkar Open University, India (Prof. Seetharama Rao, Vice-Chancellor).

(2) FernUniversität, NRW, Germany (Prof. Ada Pellert, Rector).

(3) Korea National Open University (Dr Byung-Ki Moon, Dean).

(4) Open Polytechnic of New Zealand (Dr Caroline Seelig, Chief Executive).

(5) Open University of Hong Kong (Dr K.C. Li, Director of Research).

(6) Open University of Israel (Prof. Sarah Guri-Rosenblit, Dean).

(7) Open University of Japan (Prof. Tatsuhiko Ikeda, Rector).

(8) Open Universiteit, the Netherlands (Prof. Anja Oskamp, Rector).

(9) Open University UK (Guy Mallinson, Director Strategy).

(10) Université TÉLUQ, Québec, Canada (Dr Noel Martin, Director-General).

(11) Università Telematica Internazionale UNINETTUNO, Italy (Prof. Maria Amato Garito, Rector).

(12) Universitas Terbukas, Indonesia (Prof. Tian Belawati, Rector).

(13) University of South Africa (UNISA) (Prof. Mandla Makhanya, Vice-Chancellor).

(14) Wawasan Open University, Malaysia (Prof. Ho Sinn Chye, Vice-Chancellor).

\section{Corresponding author}

Alan Tait can be contacted at: alan.tait@open.ac.uk

For instructions on how to order reprints of this article, please visit our website: 